JEASP

Journal of English for Academic and Spesific Purposes

Volume 1 Number 1, June, 2018

\title{
TEACHERS' PERSPECTIVE ON THE CHALLENGES OF TEACHING ENGLISH FOR SPECIFIC PURPOSES IN INDONESIA
}

\author{
Wahyunengsih \\ (Wahyu.nengsihhasan@gmail.com) \\ Pusat Pengembangan Bahasa Inggris \\ Universitas Islam Negeri Maulana Malik Ibrabim Malang
}

\begin{tabular}{ll}
\hline ARTICLE & ABSTRACT \\
\hline Keywords: & $\begin{array}{l}\text { Many studies related to EFL investigate that a mismatch between } \\
\text { teaching } \\
\text { challenges, ESP }\end{array}$ \\
demotivation. The implementation of ESP in Indonesia mostly adopts \\
Content-Based Instruction which requires a lot of effort from the teacher. \\
The teachers' perspectives are important to reveal the actual challenges in \\
the classroom to determine the best solution. A questionnaire was \\
distributed to around thirty lecturers of ESP to be analyzed statistically by \\
using the Likert scale to show their views on the obstacles and challenges \\
of teaching ESP. There are four domains that are analyzed which are, \\
opinions, attitudes, preferences, and perceptions of the subjects. The \\
researcher counted and found out the average score, middle point in the \\
score distribution, point where the most score was obtained, finding the \\
average deviation of each score from the mean, and percentage of the \\
proportion of the group population. From all of those calculation results, \\
the researcher derives conclusion by comparing to the result of the \\
interview as well. It comes to the conclusion that from four fields that \\
had been studied, attitudes and preferences take the highest rank of the \\
teachers' challenge.
\end{tabular}

\section{INTRODUCTION}

As the basic foundation of this study, there are two main theoretical and empirical backgrounds. Both of them reveal the essence of this study and proof that it is worth enough to give contribution toward the development of English Teaching foe Specific Purposes, especially in Indonesian context. First, teaching a foreign language certainly will have problems. However, the types of the problem will vary in every country, but it still can show the bottom lines. There are basically many principals which involve the students, the educators, government policy, social and cultural, historical, education system, and also financial problems. Some studies have been conducted related to this issue. Based on Davis (2016) there are ten problems in the ESL classroom which cover all of the items above. Other study related to problems of teaching EFL tried to investigate that a mismatch between teaching and 
JEASP

Journal of English for Academic and Spesific Purposes Volume 1 Number 1, June, 2018

learning styles causes learning failure, frustration, and demotivation. The result of the study shows that EFL teachers should teach in a balanced style in order to accommodate different learning styles (Peackok, 2001). It means, the variation of teaching strategy and method that are offered by teacher also becomes one of the problems in teaching EFL including teaching ESP in Indonesian context. Moreover, the challenges in teaching EFL emerge from the teachers' belief. As mention by some other researchers on teacher education and development studies. They have shown how teachers' beliefs play a crucial position in affecting the teachers' teaching. It also effects to the kinds of thinking and decision making that the teachers use during their classroom practices (Moon, 2000; Richards, 1998; Richards \& Lockhart, 1996; Smith, 1996; Trappes-Lomax \& McGrath, 1999).

Moreover, Indonesia is one of the countries in South East Asia which has already carried out the national education system universally and provided to all citizen. However, it cannot be denied that there are still many obstacles dealing with geographic location, religion, socio-economic background, address the differing needs of people at various stages of societal development (Sadiman, 2004). In other sides, all of the Indonesian still need to face globalization which requires the ability to use a foreign language. The Indonesian government has already anticipated this issues. Since 1979, the National Commission on Education Reform has been reporting issues of national education that relates to the quality and quantity of education. Even farther, the challenges and educational development have been read and anticipated by the Ministry of National Education of Indonesia as outlined in "the National Strategic Plan Year 2005-2009 Moving Towards Long-Term Development of National Education 2025 (Arifin:2009). However, there are still many gaps in the high success of English use among all in Indonesian or educated people specifically.

In responding to the challenges and development of education, strategic effort must be applied in order to achieve the goal. It includes continuous supervision to the national education curriculum, facilities, and also teachers' quality. Adequate teachers' quality in all levels of education must be seriously done in order to avoid failure. The anticipation of this issue has also been implemented by the 
JEASP

Journal of English for Academic and Spesific Purposes Volume 1 Number 1, June, 2018

central government through increasing the teachers' qualification and certification program. In the Act no.20 / 2003 about National Education System confirms that all teachers from kindergarten to high school should be qualified S1 degree, whereas for high education institution and university's lecturer must fulfill at least Magister or S2 degree (Budiharto, 2013).

Moreover, in Act No. 14 the Year 2005 on Teachers and Lecturers (Article 1, point 1), states that teachers are professional educators with the primary task of educating, teaching, guiding, directing, training, assessing, and evaluating students on early childhood education, formal education, primary education and secondary education. The professional teacher figure, of course, must be preceded by our formulation of the concept of professionalism which is related to the normative criteria that are generally required of a teacher as a profession. In line with the national development programs of education, one of the real applications is the inclusion of English language into the curriculum. This aims to improve the quality of Indonesian human resources. Therefore, Indonesian government specifies English as one of the required subject at school and also university level. It is mentioned in Government Regulation No. 19/2005.

However, the fact shows that the implementation of English education at school and university still provides a question mark on the quality of English language teaching itself. Majority of Indonesian students are still experiencing difficulties in communicating with this international language (Mattarima, 2011). In line with this issue, Chodijah in Weni (2016) states her statement that national educators, teachers, and also instructors of English especially at primary school level have not worked based on a clear reference and proper preparation of teacher competence. In other words, English teaching resources in Indonesia is still facing obstacles and challenges. These are as a means of international communication in practically all fields or walks of life and as a medium through which scientific knowledge and new technologies can be accessed. It is also implemented with a view to succeeding in the global marketplace. This situation leads to the answer to the question related to the level of the success of English education for more than seventy-one years in this country. With this time period of teaching and learning 
JEASP

Journal of English for Academic and Spesific Purposes Volume 1 Number 1, June, 2018

English, Indonesia should have been achieved a high level of English mastery among all expanding circle countries. This fact is in line with what Dardjowidjojo in Lauder (2008) shows in his study that reveals the fact that English in Indonesia is still in the low level of enquiring. He also says that even highly educated intellectuals often make a poor impression when giving presentations in English or find themselves unable to access academic articles written in English.

The other fact of an unexpected condition of English use in Indonesia is also shown by a study conducted by Kuswandono (2014) which focus on the English teacher's side. This research reveals that most of the participant teaching profession program seems to lack intrinsic motivation to study in their teacher education courses. This phenomenon certainly needs a deeper view of the institution that held the pre-service and in-service teacher program. In other words, today's English teachers is a valid basic evidence of the pre-service and in-service teacher program level of success. Based on the author's experience working in the field of English language teaching, most of the standardizations are measured only from the students' score in subjects that are offered in their department. Some universities use TOEFL as an indicator, but it is not used on a regular basis over a period of 8 semesters in college learning process. It is not used as a graduation requirement with certain standards. Yet, it is widely used as a standard assessment at the time of admission or determination process class division level. Therefore, most of the college graduates who are majoring in non-English language education still get TOEFL score lower than 500 .

In relation to this issue, several studies were conducted. First, a study which was conducted by Mattarima (2011) under the title "The Teaching Constraints of English as a Foreign Language in Indonesia: The Context of School-Based Curriculum" shows that there are three main factors causing aspects: (1) the government is not well and accurately informed about the feedback of its implementation for limited time, (2) the class management and teaching preparation are inadequate, (3) inappropriate assessments are applied to assess students' language skills create the contra productive in the result. All of his suggestions mainly focus on the teachers to improve their professional work ethics by: (1) understanding the 
JEASP

Journal of English for Academic and Spesific Purposes Volume 1 Number 1, June, 2018

students individual differences, (2) achieve their students positive attitudes, (3) connect those sources of positive attitude, high motivation, appropriate choice of learning strategies in designing syllabi, lesson plan, technique, and media, (4) contribute students' individual differences in developing curriculum, syllabi, and lesson plan.

The second study was conducted by Yulia (2013) which shows some results. Based on her study, it is known that teachers must be able to motivate students to learn English in an interesting way. It means, she suggests that all teachers need to participate actively to improve their teaching professionalism through pre-service and in-service training although such situation is not easily realized. Another study "Identifying Our Approaches to Language Learning Technologies: Improving Professional Development" also concludes that teachers bring integration of technology with language learning is based on upon our growing experience of providing professional development for ESL/EFL teacher trainees. This study clearly states that one of the problem solutions depends on the quality of teachers'. Then, all of the results of the previous studies show that there is a gap between the quality of the teaching and learning English with the quality of teachers of English itself. The best place to dig the problems, obstacles, and challenges of English teaching based on those previous studies conclusion and suggestion are in the level of a university as the factory of the English teachers themselves.

In fact, most of ESP programs in Indonesia adopt Content-Based Instruction in the teaching-learning process. This practice is run with some major challenges. Kusni (2013) says that the current issues in teaching ESP involve the curriculum design, teachers' overloaded hours, objectives and materials, and also the assessment. Moreover, the other study conducted by Poedjiastutie \& Oliver (2017) shows another side of issues which is basically from the students. The study involves the employers, ESP teachers, and students. The finding shows that six categories of English language learning needs were identified, namely being able to read English publications, increasing international collaboration, improving employment opportunities, improving life's opportunities, and, measuring learning outcomes. 
JEASP

Journal of English for Academic and Spesific Purposes Volume 1 Number 1, June, 2018

Based on all of the explanation above, it is crucial to figure out a more specific field of obstacles and challenges in ESP. However, this study focuses on the teachers of ESP only. It is aimed to make the more specific finding of the problem and propose the best solution to cover them. Based on the background of the problems that have already stated above, the statement of the problem in this study can be formulated as follows: "What are the teachers' perspective on the challenges of teaching English to non-English teaching department students in Indonesia?" Therefore, the purpose of this study is aimed at finding out: the teachers' perspective on the challenges of teaching English to non-English teaching department students in Indonesia. Since this study will be conducted in several universities in Indonesia, it is expected to reveal any obstacles and also challenges of teaching English at the university level in Indonesia. Practically, it is expected to see the general view of the English teaching problem itself for the future English teacher. Therefore, by figuring the problems and challenges, all English teachers find the best solution to these problems. Besides, this study will help the students of non-English teaching department to get a deeper understanding of self-evaluation method because they are already aware of the common challenges that they might face in the real teaching process. It also motivates future teacher or students of non-English teaching department to enrich their knowledge in any teaching methods in order to avoid facing the obstacles revealed by this study.

Theoretically, this study is aimed to discover new methods of teaching and methods of evaluation in English as specific purposes (ESP) teaching. Moreover, the result of this study also can be used as a basic theory which bases the future study in term of curriculum development at a university level and the arrangement of the most appropriate ESP teaching materials. This study hopefully provides the English teachers or English teaching professors a scientific study on the challenges and obstacles in teaching English and provides the English pupils an additional reference in searching the teaching of English for future English teacher program. This study is limited to the following scope: the subject of the study are some lecturers and students which are selected randomly in non-English Teaching Department of each university. 


\section{METHOD}

This study reveals objective opinions, attitudes, preferences, and perceptions of the subjects on the teaching and learning of English as a foreign language in Indonesian English teaching, particularly at university level. It is aimed to analyze challenges that lecturers or teachers' trainers face in preparing the future teachers and at the same time reveal the challenges faced by undergraduate students of nonEnglish department. However, the amount of the population will be based on the real numbers of the population in each sample. A questionnaire survey is used to get the data from both the ESP lecturers and students. Interview with some samples from teachers and also students are conducted. The samples in interview are selected randomly. Moreover, this study also employs classroom observation to some randomly chosen class in each location. This is aimed to observe the real situation during the teaching and learning process. The questionnaires addressed to the teachers examine the issues related to ESP teaching facilities and professional development activities included research conducted by those lecturers. Meanwhile, the questionnaires administered to the students focuses on satisfaction opinion, motivation, learning facilities, and teachers' quality. Those parts will be measured on three points Likert-type scale.

The subjects of this study are the lecturers of non-English teaching departments from several public and also private universities in three major locations. This study will be conducted in several universities that have decades of experience in English language education for prospective English teachers in Indonesia. In this case, the researchers choose the subject of research at the State University of Malang and Malang Muhammadiyah University. There are several reasons to select those universities. In terms of the location, it will be chosen by using purpose sample technique in order the guarantee the representative of the samples. First, the location of these universities represents Indonesia region western parts of Indonesia. These two universities represent higher education institutions that manage the non-English teaching department managed by private parties. However, this survey involves large numbers of the population which are selected by using random sampling technique. Second, to the above four universities have produced in 
JEASP

Journal of English for Academic and Spesific Purposes

Volume 1 Number 1, June, 2018

thousands of alumni. They have already experienced English language teaching as a permanent and freelance teacher in various regions throughout Indonesia. With a high quantity of graduates and also the high level of experience in managing English language teaching, it is expected that this study can obtain complete and valid data.

Moreover, students of non-English teaching department are also taken as the subject of this study in order to reveal an objective and valid data from the main future products of the department. A questionnaire survey of both teachers and students of the universities are employed to gather the data. In order to get deeper analysis then interview to at least 10 lecturers in each university and 10 students that will be taken randomly also take an important role to get the data in this study. As well as the questionnaires and also interview, an observation to teaching-learning process to at least 5 subjects will be done in order to mix and match the information taken from the previous instruments to the real situation during the teaching and learning process.

The procedure and sampling technique talk about the steps of selecting the samples. The procedure is started by seeing certain phenomenon the samples which are divided into three sections: alumni of non-English teaching department that take ESP class, recently ESP class students, and also lecturers of ESP classes. It is also basically based on the phenomena that are happening in the field of English education in Indonesia, especially the field of the result of English educators' competency. It reveals the result of English Proficiency Test such as TOEFL and TOIEC which were held for teachers and also future teachers from English department students. To ensure this data, the researchers will gather all information related to their result in proficiency test that they had been taken before.

In this study, the researcher uses the questionnaire as the instrument in doing the research in order to identify the challenges that they face in teaching ESP at the university level. The questionnaire is used in this study to cover the large sample as mentioned in Latief (126:2012). Arikunto (2006:151) also says that questionnaire could be in the form of multiple, essay, check-list and rating-scale, so respondents would only select one of the provided answers in it. In conducting this study, the researcher will use Likert questions. Likert questions can help the researcher ascertain 
JEASP

Journal of English for Academic and Spesific Purposes

Volume 1 Number 1, June, 2018

how strongly the respondents agree with a particular statement which leads to the issues that potentially cause constraints in teaching and learning English. Such type of questions also helps to assess how students and also lecturers feel towards a certain issue related to the government policy, product or service in the field of ESP teaching and learning. The questionnaire is developed by the researcher by adapting statements that are taken from the previous similar study that was conducted in the South East Asia area. The questionnaire is tried out to some members of the similar group. The item analysis and expert validation are also included as the step of constructing the final form of the questionnaire. Besides that, since the use of the questionnaire as the only instrument potentially gives bias result, therefore interview is also used to follow up the questionnaire. However, the interview samples are taken randomly in limited numbers.

To collect the data, there are several steps that are going to follow. First, the questionnaire is distributed to at least sixty-five percent of the total population of the lecturers at each selected campus. It is aimed to get the propositional amount of respondents to fulfill the questionnaire. It is expected that the result of the data analysis will give an accurate description of the real problem faced by the lecturers as the stag holder in this education level. In all of the selected universities, the researcher does those process at different times. Since the researcher presence to control the distribution in each campus is very crucial, therefore it cannot be done at the same time. The researcher determines all of the other members that help to distribute the questionnaire are giving that form to the right target. Meanwhile, the researcher also conducts an interview to some of the lectures and also some of the ESP students to make sure the quality of the answers that are given in the questionnaire are far from bias.

All the data taken from the questionnaire is analyzed statistically. The researcher counts and finds out the average score, middle point in the score distribution, point where the most score was obtained, finding the average deviation of each score from the mean, and percentage of the proportion of the group population. From all of those calculation results, the researcher derives conclusion by 
comparing to the result of the interview as well. It means the data analysis uses descriptive statistics

\section{FINDINGS AND DISCUSSION}

Findings

There are four domains that are analyzed which are, opinions, attitudes, preferences, and perceptions of the subjects.

\section{Opinion}

Opinion covers the professional development thought that is reflected in their activities that develop their skills, knowledge, the expertise they have ever done as ESP teachers. Based on the questionnaire, it shows that eighty percent of the teachers answer that students are often encouraged to take extra courses/workshop on the subject. However, there is no teachers' answer that can reach that the students encouraged to take extra course most of the days. The teachers' answer related to the opinion of this subject that can reach high percentage is the students are monitored by the lecturers in that particular subject or other subjects to read professional literature and some other items in professional development such as, classroom management, instructional practice, students' understanding, and can serve in multicultural setting. However, the challenges reveal on these following parts which reach almost ninety percent of the teachers' answer them in the lowest score:

1. Students are rarely assigned to do observation and visit other department or other universities.

2. Students are rarely recommended to participate in a network of teachers formed specifically for professional development.

3. Students are rarely trained the individual or collaborative research on a topic of interest to research grand or competition.

4. Students are also rarely guided in mentoring peer observation and coaching as a part of a formal college arrangement. 
It can be inferred that in terms of opinion in the professional development, teachers still face issues and challenging to place the students' motivation and create activities that can improve their professional development.

\section{Attitudes}

The attitude involves students' motivation from the teachers' point of view. It covers the students' effort, desire, and effect in learning English. Among twentyone, questions address there two major problems that raise. The first is the students simply quote the textbooks and do not really communicate themselves in their productive skills products such as speech or writing. The second is that studying English rarely ensures the students to use it to discuss interesting topics in English with people from other national backgrounds. The other problem in motivation that the teacher face really difficult to make the students feel that they were proficient in English makes other people respect them more. They tend to put all priority on their mastery on their own major away higher than English mastery.

\section{Preferences}

There are several fields that are discovered in this part. They are teaching practice preferences, and beliefs. The problems revealed are:

1. There are very limited ESP teachers that prefer team teaching as the professional activities.

2. There are few of the lecturers or teachers that observe the other teachers' class and give comment and feedback on their partners' class.

3. There are only lower than fifteen percent of the teachers that engage in joint activities across different classes and age groups projects.

4. It is also few of the teachers assign the students to discuss and coordinate homework practice across subjects.

\section{Perception of the Subject}

Teachers' perception of the subject focuses on the curriculum and also policy. The curriculum here means the total learning experience that should be 
JEASP

Journal of English for Academic and Spesific Purposes

Volume 1 Number 1, June, 2018

learned by students in the educational institution. The policy is defined as a set-out principle that the university follows in developing English language proficiency in undergraduate courses. The major problems can be seen from:

1. There is limited participation on the department official or someone else in the management in the ESP curriculum development.

2. Both of the universities send lecturers to work on a department or university's development plan.

3. Only a few of the department official get involved to define goals to be accomplished by teachers of ESP.

\section{Discussion}

Based on the finding above, the teachers' perspective on the challenges of ESP teaching indeed emphasized on the professional development program that is not authentically provided. There are very limited programs that lead the students to experience the real effect of mastering English in their professional field. It also happens in during the process of curriculum development that lecturers are rarely supported by the official departments and university policy to give actual project for ESP course. This once again shows what has been mention by Kusni (2013) that the current issues in teaching ESP involve the curriculum design, teachers' overloaded hours, objectives and materials, and also the assessment.

In terms of the attitudes, preferences, and perceptions of the subject, the major problems also appear when it deals with the difficulties to make the students proud and effective to master English in their major. The teachers also take part in making this problem worse since very few of ESP lecturers prefer to work individually rather than collaboratively making a team teaching. Poedjiastutie \& Oliver (2017) shows shows that six categories of English language learning needs were identified, namely being able to read English publications, increasing international collaboration, improving employment opportunities, improving life's opportunities, and, measuring learning outcomes, yet these are still cannot be placed in the highest position of main activities done by lecturers and students during the ESP course. 
JEASP

Journal of English for Academic and Spesific Purposes

Volume 1 Number 1, June, 2018

Moreover, the developing positive attitudes and perception is urgently done by opening the students' global perspective. Students must experience all of the needs of English in the real world. It is clearly important to give ESP students the actual experience of employing English to increase their expertise, giving better and higher chance for good career. Yulia (2013) mentions that teachers must be able to motivate students to learn English in an interesting ways. Therefore, they will be able to measure their learning outcome with the actual need in the work field and this way potentially as the most interesting way to motivate the students. However, the teaching learning process do not only focus on the teacher but must be fully supported by all other elements in academic field, stag holder and the parents and also goverment.

All of the finding above, stating the previous study conducted by Mattarima (2011) focusing on the third aspect of teaching constrains in teaching EFL in Indonesia which connect those sources of positive attitude, high motivation, appropriate choice of learning strategies in designing syllabi, lesson plan, technique, and media, and the fourth which require the students to contribute individual differences in developing curriculum, syllabi, and lesson plan. Designing ESP course program must collaborate in all circles of the system academically and nonacademically. It means that standard program of curriculum of ESP in Indonesia must be developed in specific field of major and cannot be equalize to all in general.

\section{CONCLUSIONS AND SUGGESTIONS}

The recent study shows that the teachers' perspective on the challenges of ESP teaching dominantly emerges on the opinion on the professional development, preferences, and perception of the subject. Even though, among all of the major principles of ESP teaching are already qualified enough, but the most of the challenges come from some major element of ESP teaching such as curriculum development and also policy that creates the real goal of the ESP itself which is aimed to make all ESP students improve their mastery and professional skills in their actual major by using English as one the means to reach that achievement. 


\section{JEASP}

Journal of English for Academic and Spesific Purposes

Volume 1 Number 1, June, 2018

Since this study still cannot give further investigation on the students, alumni, and stag holders as the part of the research, it is highly recommended that further study must be conducted separately based on each ESP classes based on the students' majors. Content-Based Instruction for various types of major in the university must require different demand in the actual professional fields. So, the involvement of students, alumni, and also stag holder as the user of the alumni can be covered. Then, the best policy, curriculum and other specific solution to those challenges can be formulated effectively.

\section{REFERENCES}

Akbari, Z. (2015). Current challenges in teaching/learning English for EFL learners: The case of junior high school and high school. Procedia - Social and Behavioral Sciences, Vol. 199 Page 394 - 401.

Alharbi, A. A. (2015). Improving Students' English Speaking Proficiency in Saudi Public Schools. International Journal of Instruction, Vol. 8, No.1 Page 105-116.

Al-Jamal, D. A. \&. Al-Jamal, G. A. (2014). An Investigation of the Difficulties Faced by EFL Undergraduates in Speaking Skills. English Language Teaching, Vol. 7, No. 1 Page 19-27.

Alkhawaldeh, A. (2010). The Challenges Faced by Jordanian English Language Teachers at Amman 1st and 2nd Directorates of Education. Retrieved on 6th of December 2016 on https://www.questia.com.

Arikunto, S. (2006). Prosedur Penelitian: Suatu Pendekatan Praktek, Edisi Revisi, PT, Rineka Cipta, Jakarta.

Arifin, Z. (2009). Evaluasi Pembelajaran. Bandung: PT. Remaja Rosdakarya.

Alyan, A. A. (2013). Oral Communication Problems Encountering English Major Students: Perspectives of Learners and Teachers in Palestinian EFL University Context Arab World English Journal, Volume.4 Number.3, Page.226-238.

Bolton, K. \& Kachru, B. B. (2006). World Englishes Critical Concept in Linguistics. Routledge: New York.

Davis, J. (2016). Teaching ESL: 10 Common Problems in the Classroom. Retrieved on https://owlcation.com/academia/Teaching-ESL 30th of November 2016.

Elyas, T. \& Al Grigri, W. H.A. (2014). Obstacles to Teaching English in Saudi Arabia Public Schools: Teachers' and Supervisors' Perceptions. Retrieved on August 23rd, 2016 on www.eajournal.org. 


\section{JEASP}

Journal of English for Academic and Spesific Purposes

Volume 1 Number 1, June, 2018

Kautsar \& Yunial, S. D. (2012). Pengaruh Persepsi Siswa Tentang Keberadaan Guru Ppl Mata Pelajaran Bahasa Jerman Terhadap Minat Belajarnya. Retrieved on 12th of January 2014 on journal-online.um.ac.id

Kirkpatrick, A. (2012). English in ASEAN: Implications for Regional Multilingualism. Retrieved on 15th of January 2016 on http://www98.griffith.edu.au/dspace/bitstream/handle/10072/52188/85961 1.pdf

Kusni. (2013). Reformulating English for Specific Purposes (ESP) In Indonesia: Current Issues And Future Prospects. SELT 2013 Proceeding.

Kuswandono, P. (2014). University mentors'views on reflective practice in microteaching: building trust and genuine feedback. Reflective Practice, Vol. 15, No. 6, 701-717.

Kuntz, P. S. (1996). Beliefs about Language Learning: The Horwitz. Model. Retrieved on 23rd of December 2016 on http:/ / files.eric.ed.gov.

Lakshmi, Bh.V.N. (2013).Challenges in Teaching Language and Literature: An EFL Perspective. IOSR Journal Of Humanities And Social Science (IOSR-JHSS), Volume 15, Issue 6 PP 49-53.

Latief, A. (2012). Research Methods on Language Learning an Introduction. Malang: UM Press.

Lauder, A. (2008). The Status and Function of English in Indonesia: A Review of Key Factors. Retrieved on 12th of January 2016 on https:/ / www.researchgate.net.

Lestari, N. T. (2012). Profesional Guru dan Tanatangan Sebagai Profesi. Retrieved on 12th of June 2016 on http://www.kompasiana.com.

Loubazid, M. (2012). Exploring the Difficulties Facing EFL Students' Participation in Oral Expression Course The case study of third-year LMD students at Biskra University. Biskra: Unpublished Dissertation.

Mahrooqi, Rahma Al \& Denman (ed), Christoper. (2015). Issues in English Education in the Arab World. Cambridge Scholar Publishing.

Mattarima, K, \& Hamdan, A.. R. (2011). Learners' Motivation And Learning Strategies In English Foreign Language (EFI) In Indonesian Context. Journal of Edupres, Volume 1 September 2011, Pages 100-108.

Megawati, F. (2015). Challenges in Teaching EFL for Pre-Service Young Learner Teachers. Proceedings The 62nd TEFLIN International Conference 2015. Page 847888. Denpasar: TEFLIN International Conference.

Mistar, J. (2005). Teaching English as a Foreign Language (TEFL) in Indonesia. In G. Braine (ed.), Teaching English to the World: History, Curriculum, and Practice (pp. 75-85). New Jersey: Lawrence Erlbaum Associates, Inc.

Moon, J. (2000). Children learning English. Oxford: Macmillan Heinemann. 


\section{JEASP}

Journal of English for Academic and Spesific Purposes

Volume 1 Number 1, June, 2018

Peackok, M. (2001). Match or mismatch? Learning styles and teaching styles in EFL. International Journal of Applied Linguistics, Volume 11, Issue 1June 2001 Pages 120.

Poedjiastutie, D. \& Oliver, R. (2017). English Learning Needs Of Esp Learners: Exploring Stakeholder Perceptions at an Indonesian University. TEFLIN Journal, Volume 28, Number 1, January 2017.

Pribadi, A. K. (2016). English Teachers" Obstacles in Teaching and Learning at SMP Negeri 1 Moyudan Sleman. Retrieved on August 23rd, 2016 on www.englishacademia.edu.

Richards, J. C. (1998). Beyond training. Cambridge, U.K.: Cambridge University Press.

Riley, P. A. (2006). The Beliefs of First Year Japanese University Students Towards the Learning of English. Retrieved on 23rd of December 2016 on https://core.ac.uk.

Sadiman, Arief. S. (2004). Challenges in Education in South East Asia. SEAMEO SEAMOLEC, India. Retrieved on 16th of February 2015 on www.seameo.org.

Shinde, M. B \& Karekatti, T. K. (2012). Pre-service Teachers' Beliefs about Teaching English to Primary School Children. International Journal of Instruction, Volume 5, Number 1, Page 69-86.

Smith, D. B. (1996). Teacher decision making in the adult ESL classroom. In D. Freeman \& J. C.Richards (Eds.), Teacher learning in language teaching (pp. 197-216). Cambridge, U.K.: Cambridge University Press.

Trappes-Lomax, H., \& McGrath, I. (Eds.). (1999). Theory in language teacher education. Harlow, Essex, U.K.: Longman.

Vickers, A. (2009). English Language Teaching in Indonesia. Retrieved on 23rd of February 2014 on http://blogs.usyd.edu.au.

Weni, S. (2016). Bahasa Inggris di SD; Kebijakan, Guru dan Siswa. Retrieved on 28th of September 2016 on http://www.kompasiana.com.

Yulia, Y. (2014). An Evaluation of English Language Teaching Programs in Indonesian Junior High Schools in the Yogyakarta Province. Retrieved on 12th of January 2014 on https://researchbank.rmit.edu.au.

Yuwono, G..I \& Harbon, L. (2010). English Teacher Professionalism and Professional Development: Some Common Issues in Indonesia. Asean TEFL Journal, Volume 12 Issue 3 September 2010, page 145-163 